\title{
Intelligence and Mind Games in Concept Teaching in Social Studies ${ }^{1}$
}

\author{
Sibel Çağı* \\ Department of Turkish and Social Sciences Education, Institute of Social Sciences, Yıldız \\ Technical University, Istanbul, Turkey. \\ ORCID: 0000-0002-8312-1152
}
Şahin Oruç
Social Sciences Education, Faculty of Education, Ylldız Technical University, Ístanbul, Turkey,
ORCID: 0000-0001-8666-3654

\begin{tabular}{|c|c|}
\hline & \multirow{7}{*}{$\begin{array}{l}\text { In the Social Studies lesson, the impacts of using intelligence and mind } \\
\text { games on academic achievement and students' attitudes towards Social } \\
\text { Studies lesson were examined for the teaching of the concepts in the 6th } \\
\text { grade Effective Citizenship Learning Area. In the study, semi- } \\
\text { experimental pattern with pre-test-post-test, experimental-control group } \\
\text { was studied. In the research, teaching the concepts with intelligence and } \\
\text { mind games prepared by the researchers was carried out with the } \\
\text { experimental group. On the other hand, the control group was taught in } \\
\text { line with the activities in the current curriculum. As a result of the t-test } \\
\text { analysis of the pre-post-application scores of attitude in the control and } \\
\text { experimental group, it was observed that there was a significant } \\
\text { difference in favor of the post-test both in control group ( } \mathrm{t}=-2.955 \text {, p } \\
<.05) \text { and in experimental group }(\mathrm{t}=-4.109, \mathrm{p}<.05) \text {. As a result of the } \\
\text { research, a conclusion was reached in favor of the experimental group in } \\
\text { terms of both academic achievement }(\mathrm{t}=-7.028 \text {, p <.05) and attitude } \\
\text { towards the course ( } \mathrm{t}=-2.411, \mathrm{p}<.05) \text {. Intelligence and mind games can } \\
\text { be used to teach the concepts of the Social Studies course. Mind games } \\
\text { named "Tick Tack Concept" (Tik Tak Kavram Oyunu) and "Keep in your } \\
\text { mind" (Aklinda Tut) which were developed in this study can be used for } \\
\text { concept teaching. }\end{array}$} \\
\hline Received: & \\
\hline & \\
\hline & \\
\hline & \\
\hline & \\
\hline & \\
\hline
\end{tabular}

\section{Introduction}

In order to learn the principles of social studies and to solve social problems, it would be highly useful for the students to learn the basic concepts. Concepts contribute to the formation of cognitive structures in the long-term memory of individuals and to the process of making meaningful storage of new information coming into memory. Therefore, in order for students to learn concepts in a meaningful way, importance should be given to concept teaching

\footnotetext{
${ }^{1}$ This article was produced by Sibel Çağır's Master's Thesis in the Teaching of Social Studies Concepts in the field of Turkish and Social Studies Education in Yıldız Technical University in 2020.

*Correspondency: cagirsibel@gmail.com
} 
(Erden, undated, 49).

There are plentiful studies regarding the teaching, difficulty and misconceptions of concept learning and its importance. How the concept is taught is of equal importance to the importance of the concept. To that end it is fundamental to use different methods and techniques in concept teaching in order to prevent misconceptions that might occur, to touch the life of the individual and to carry out the education process as desired.

Erden (Undated,138), who thinks that educational environments should be fun, emphasizes that so as to enable learning in a fun school environment, it is necessary:

- To ensure the effective participation of children throughout the learning process,

- To give students the opportunity to learn by doing-living,

- To make sure that learning evolves into a play style.

Today, as in every field, together with the rapid advances in technology, changes and development have been witnessed in games. Games appear in the form of intelligence games has gained a wider usage. Moreover, the importance of these games has increased with their insertion to the curriculum as an optional course by the Board of Education and Discipline (TTKB) (2013). Thus, as the attributed value to the intelligence games increases, their potential enhances.

Social Studies is a curriculum designed to combine knowledge and methods from social and humanities with the aim of raising effective citizens who can come up with solutions to problems, make decisions based on knowledge in a world where countries and world conditions change in almost every sense (Öztürk, 2012, 4). In fact, social studies cover a large number of concepts due to being an interdisciplinary course and have a wide scope. Thereupon, it is essential to learn the concepts that are important in all areas of life and to understand the concepts of social studies through the ones that are of abstract nature. However, concepts and especially those that are abstract in general are difficult to teach and learn. Misconception occurring for the individual or not learning the concept might cause incomplete or incorrect learnings at other stages. That said, it is important for today's individuals to be taught in a fun way, through which they can be active and excitement and success are assured, and it is vital that right learning takes place leaving no room for misconceptions.

In the Social Studies course, concept teaching first gained a significant aspect in light of the conceptual approach between the years 1960 and 1970 (Erden, undated, 49). Social sciences emerged under the name of social studies in the form of an interdisciplinary field and integrated formal education program in primary education. The content of social studies course is indeed very rich in terms of concepts as it is shaped within the scope of social sciences. Within the framework of the Social Studies course, students face many concepts related to several disciplines viz. geography, history, anthropology, political science, economics, sociology, psychology, and others (Tokcan, 2015, 1). Among the objectives of the primary school Social Studies course the following exists: students could understand various social concepts related to the units. When children attend primary education, they encounter some social concepts for the first time in their lives. It is often difficult for children to understand these concepts that they come across for the first time and as a result, confusion of these concepts or misconceptions occur. This situation causes students not to learn the subjects well, in particular in situations in which inadequate equipment is used to teach (Yazıc1 and Samanc1, 2003). The Social Studies course has a program with extensive content. Having a comprehensive content has also enriched 
the concepts of this area. Learning the units of the Social Studies course requires the fact that a fair number of concepts are internalized. As a matter of fact, it becomes a priority to help learners gain meaningful knowledge about concepts in all units of the course. Concepts are of utmost importance in that children would regulate the complex structure of the facts through concepts and avoid being captivated in the depth of the details (Kürümlüoğlu, 2019, 21). Concepts actually enable individuals to express their feelings, thoughts and experiences, hence communication between individuals is developed and sustained. This situation is one of the determinants of the life limits of the individual and creates richness by adding different meanings to their life. Social Studies, thence, aim to assist individuals in producing sophisticated meanings about the concepts of social sciences making it an interdisciplinary course (Sabanc1, 2015, 200-206). When the concepts of Social Studies as an interdisciplinary course are examined, it would be fair to state that each concept comes from almost all segments of a life of an individual. This attaches more value to the teaching of the concepts of social sciences. It can be said that the more methods and techniques are developed for the correct and permanent learning of these concepts eliminating misconceptions, the more benefits emerge for the individual.

It is meaningful here to acknowledge that concept teaching and concept learning are different concepts. For this reason, learning and teaching are carried out with differing techniques and methods. In this sense, there are varying techniques that can be used for concept teaching. Concept teaching techniques according to Tokcan (2015, 51-438) are; "Concept Maps, Mind Map, Concept Networks, Fishbone Diagram, Structured Grid, Diagnostic Branched Tree (DBT), Meaning Analysis Tables, Concept Cartoons, Information Maps, Conceptual Change Texts, Word Association Test (WAT), Concept Puzzles, Two-Stage Diagnostics Test, ThreeStage Diagnostic Test, Guess Observe Explain, V Diagram". Stating that concept learning is the basis of cognitive development, Senemoğlu (2015, 516-533) utters that there are four stages of concept learning. These levels follow from bottom to the top as "concrete level, recognition level (identity level), classificatory level, abstract level (formal level)”.

In addition, in this era, it is not sufficient for individuals to solely obtain information, they are to continue their social lives with the help of that very information and thusly keep up with the age. Today, individuals need to develop their psychomotor skills and affective skills as well as active and cognitive skills in a holistic fashion. In order to be able to comply with today's conditions, individuals should be creative and at this point researching, thinking, generating ideas, having a critical perspective, and constantly developing are all indispensable. This need might be fulfilled basically through education. To put it in another way, these skills and achievements should be acquired via education. This is a situation that should be taken into consideration beginning from the earliest years of education. In 2023 Education Vision, the Ministry of National Education focuses on the necessity of establishing "Design-Skill Workshops" for the development of children's interests, abilities and temperaments (2023vizyonu.meb.gov.tr). There intelligence and mind games appear as workshops that will activate and develop children's skills.

Games have been around since the existence of living creatures (MEGEP, 2009, 49). In general, games, and particularly intelligence and mind games which develop children's cognitive, affective and psychomotor skills and support their self-regulation skills can be shown amongst the most pivotal educational tools for the child. Intelligence and mind games are core instruments that can be utilized at the primary education level in order to provide individuals with the goals that can be referred to whilst trying to catch up with the needs of the current changes. 
According to Gürgil $(2011,3)$, the goal of raising modern, democratic individuals who can keep their finger on the pulse of the age is only possible through well-designed educational environments. These educational environments are the only contexts where the individuals can show their creativity and reveal their feelings and thoughts easily.

Children spend most of their days in the school environment from the moment they turn the school age and children make an extraordinary effort to have fun (Oruç, 2006, 56-62). The more the child plays game the more he/she gets happy. A child who plays a game is a healthy child. When the child releases energy that creates tension, he reaches a healthy balance (Koçyiğit et al, 2007, 330). Intelligence and mind games also allow children to have fun while learning. As they spend most of their days in school, it is important to provide games for children with instruments such as intelligence and mind games in the school environment.

Just like games and toys, intelligence and mind games are among the oldest of the known play materials of humanity. Taking a glance at the history, it is observed that stones are important elements among game objects in different countries and cultures, as well as being the oldest game tools, and again, the oldest games are stone games. "Five Stones", which is one of the games of intelligence and mind today, is a game dating back to ancient times (Çalışkan and Karadağ, 2014, 11).

In today's world, intelligence and mind games constitute alternative educational materials serving against some negative situations brought by technology, which leads to changes and progresses rapidly. Some non-educational games offered by technological devices to students make individuals addicted and keep them away from being social. Whence, it is focal for the individual to lean to games that will stimulate socializing, having fun, learning, as well as developing the skills and abilities which are integral for a person to lead a quality life. Intelligence and mind games are means that function in this sense.

Intelligence and mind games create a game environment for children. The educational function of the game is expressed by Razon (1985) as to make the child learn about the objects around via the game and learn how to use them. With the game, the child learns the concepts of smallbig, heavy-light, many-few and so on. The child also gains the ability to distinguish colours, shapes and sizes with games. The game in learning environments helps the child to develop their ability to produce, contributing to self-expression, developing a sense of solidarity by sharing; in a similar vein aids in finishing his work, in developing their sense of responsibility and problem-solving skills establishing a cause-effect relationship and developing muscle skills (Metiner, 2018, 3).

The intelligence games in the educational game category include tangram, chess, word hunt, jigsaw, sudoku, kendoku, checkers, corridor and so on. In the general framework, intelligence games are called as a set of activities carried out in order to enable the individuals to have fun, to recognize their own talents, to produce correct and effective solutions to problems, and to renew themselves (Şeb, Bulut Serin, 2017). It is seen that intelligence games consist mainly of two dimensions as educational dimension and entertaining dimension. It is thought that they are more useful for children, especially considering the self-development dimension (Marangoz, Demirtaş, 2017). It is noteworthy that children get acquainted with intelligence games at an early age, specifically in terms of their cognitive development. Intelligence games are usually thought to be constitutive tools for developing children's thinking skills such as problem solving, analysis, and building relationship (Adalar, Yüksel, 2017). When the TÜZDER (2013) program is examined, the skills that intelligence games develop in children 
are associated with entrepreneurship, empathy, discipline, self-control, internal motivation, self-efficacy, courage and self-confidence. Intelligence games are also remarkable for mental exercises (Ott, Pozzi, 2012). In addition to increasing the mental and cognitive capacities of students, intelligence games support students' social development with the effect of group games they are consisted of, and they learners can boost their self-confidence and continue their paths by finding solutions to their failures (Marangoz, 2018). When 21st century skills are examined, it is witnessed that the skills to meet the needs of the age are high level thinking and problem solving skills. In this respect, as well as transferring information to learners, teaching of high-level thinking skills should be of concern. With regard to that, intelligence games serve as a supportive material in the teaching and development of higher-level thinking skills by providing individuals with opportunities of learning; doing, collaborative learning and active learning. Intelligence games are important educational tools as to revealing the knowledge and skills that children already possess, putting knowledge, skills and potentials into practice in different environments through practices, and enabling individuals to establish relationships among learnings by making their learning situations meaningful (Sevinç, 2004).

Intelligence games emerge from the techniques that can be used to provide high-level life skills, which is one of the main objectives of today's education system. Intelligence games such as Sudoku, jenga, corridor, word game, rubik's cube, checkers are thought to have very intensive exercise on the human brain. Besides, it is thought that individuals who play intelligence games develop many skills such as analytical thinking, practical decision making, and problem solving, along with these, they help the protection of the body against diseases related to brain (Türkiye Zekâ Vakfı (Turkey Intelligence Foundation), 2017).

Secondary School and Imam Hatip Secondary School Intelligence Games Lesson (5, 6, 7 and 8th grades) accepted at 14/09/2012 with the motion numbered 163 by the General Board of Basic Education in line with the resolution numbered 43769797/101/2175605 and dated 23/08/2013. In the curriculum, it was decided that the course is gradually given starting from the 5th and 6th grades as of 2013-2014 academic year (TTKB, 2013). When the curriculum of MoNE (MEB) for intelligence is games examined, it could be found out that a graded teaching approach is used for intelligence games in general. In the practical dimension of the program, it is seen that teachers develop the program by considering the characteristics of the students within the framework of the graded curriculum approach rules. What is more, it is pronounced that the games in the curriculum are not limited and intelligence games suitable for the students' interests can be integrated in the program. When forming the learning areas of the program, memory games, verbal games, geometric games, strategy games, transaction games and intelligence questions games can be used within the specified framework.

Devecioğlu and Karadağ $(2014,43)$, have defined intelligence games as activities that permit individuals to be aware of their potential, to produce their own/unique solutions to the problems they encounter, to make correct and rapid decisions, and to continuously innovate in themselves.

Intelligence and mind games can be defined as entertaining, instructive, and remarkable game materials that are prepared to develop individuals' mental, affective and psychomotor skills.

Intelligence games are also among the important games in educational game types. An intelligence game for which a person uses his logical problem solving skills and some strategies and solve a problem, have the functions of supporting the thinking processes and educating the brain. According to Griffiths (1996), intelligence games have such functions as encouraging 
learning, having an educational component, and changing people's negative opinions about the game. Bottino and Ott (2006) underline that intelligence games support the individual with respect to developing logical reasoning, strategic thinking and thinking skills. In addition to learning activity, it can be emphasized that intelligence games have effects that support behavior-based education such as focusing, attention-raising, increasing motivation and developing positive attitude towards learning. Intelligence games are a group of activities that are prepared to increase self-confidence, divergent thinking, and most importantly, they constantly encourage individuals to improve themselves in making fast and accurate decisions. In this respect, intelligence games not only improve the mathematical intelligences of the individuals, but also develop their strength in processing and strategies, their logic and reasoning power, visual and verbal intelligence, three-dimensional thinking, problem solving, along with helping them develop a unique approach, creating shapes, producing tactics, and creative and critical thinking skills (Devecioğlu, Karadağ, 2014).

With the technological developments, games have become an indispensable entertainment and occupation area in children's life. For this reason, it is purposeful to focus on games also in the sphere of education. It is known that there are a number of approaches to use games in the educational process. With that being said, it is still difficult to develop games in general, and it is expected that they should be entertaining as well as being adaptable to all units. The absence of these games emerges as a challenge. In another aspect, intelligence games can now be played on simple devices in digital or non-digital ways. Integration of intelligence games into the educational process would bring different outcomes for students, both cognitively and. Intelligence games are potential materials that can be resorted to with a view to enhancing intrinsic motivation, providing active and social learning opportunities, and developing cognitive and affective skills (Demirel, 2015, 8).

It can be accentuated that intelligence and mind games are capable of addressing not only mathematics or verbal intelligence but also multiple intelligence areas. In this sense, it is relevant to discuss multiple intelligence theory.

Howard Gardner, the founder of Multiple Intelligence Theory, pinpoints that the human brain consists of a modular structure and the brain is able to perform psychological operations using verbal, numerical, visual, linguistic and mimic symbol systems. (Gardner and Hatch, 1990). With this theory, Gardner makes a different definition of intelligence, not as talent or skill, but rather discusses it as the abilities that individuals have or skills that individuals own within the framework of intelligence. In that case, Gardner defines intelligence as the ability to solve problems and to create a new product in rich natural environments (Oruç, 2019, 138).

Multiple intelligence theory shows us that new methodology is needed in concept teaching. The positive results of the activities conducted in conjunction with the multiple intelligence theory indicate that multiple intelligence theory should be paid attention in the concept teaching process. It is worthwhile to have adopt approaches or turn to alternative activities in concept teaching regarding the multiple intelligence theory (Köksal, 2006, 479).

Multiple intelligence theory demonstrates us that there may be differences in the abilities and skills of each child in parallel with their developing intelligence field. On this account, the game preferences that are elementary for children's experiences can also be selected accordant with the individual's abilities and skills. Also, paying attention to multiple intelligence theory in concept teaching is required in relation to not having misconceptions and making concept learning easier. Resultantly, intelligence and mind games with various categories and types 
might be important objects of multiple intelligence theory by appealing to more than one skill area and intelligence. Intelligence and mind games are objects that help and develop the abilities of the individual in the psychomotor area, cognitive area, affective area, linguistic area, and social area. In addition to these, a requirement of multi-intelligence theory is that there should be different and multiple learning environments. If each individual can develop in different intelligence areas, tools that provide multiple environments such as intelligence and mind games would also be fruitful in educational environments.

In general, from the students' perspectives, social studies lesson is considered as one which is boring and hard to understand, not internalized, and in which learners need to memorize some information about the life of other people. We need to change this situation by making use of the approaches called constructivism or active learning by turning the course into an understandable one full of reativity. (Ata, 2012, 34). The use of materials has an important place in the Social Studies course. It is recommended to use materials in Social Sciences programs prepared with a constructivist approach. It is understood via the programs that the material use of teachers in classroom settings is also supported by MoNE(MEB) (İlhan, 2016). The game might be expressed as activities that encompass a large number of learning experiences having positive effects on learning and learning environments pinpointing the role and function of making the student active. For this reason, it can be among the important materials that can be made use of in the social studies course.

The specific objectives of the Social Studies Curriculum (MEB (MoNE), 2018, 8) are consisted of the ability of individuals who know how to obtain accurate and reliable information and who also have critical thinking skills. The use of intelligence games that have positive effects on the critical thinking skill of the individual or that would foster this skill in the social studies course will yield positive results.

\section{The Purpose of the Study}

Today, as in every field, with the rapid advances in technology, there have been considerable changes and developments in the area of games. Games have gained a wider aspect and come together in the form of intelligence games that combine with the material aspect. Furthermore, the importance of these games has gained prestige with the acceptance of TTKB (2013) as an elective course in the curriculum. Accordingly, as appreciation of intelligence games increases, their potential continues to get bigger.

Increasing awareness of the importance of concept teaching in regards to social studies and the belief that educational environments should be fun environments where students are active facilitated this research by combining the assumption that game and concept teaching can be realized in a fun dimension in this context. Therefrom, the aim of the study is to examine the impact of teaching the concepts of Effective Citizenship Learning Area with intelligence and mind games in Social Studies lesson on students' academic achievement and their attitudes towards Social Studies lesson.

\section{The Significance of the Study}

From the very moment children reach the school age, they spend a whole part of their days in the school environment, and the children make an extraordinary effort to have fun (Oruç, 2006, 56-62). Intelligence and mind games also pave the way for having fun while learning. Since 
they spend most of their days at school, it is important to provide games for children such as intelligence and mind games in the school environment.

Within this framework, the Ministry of National Education added intelligence and mind games as selective courses to the program in 2013-2014 where the creative, cognitive, affective and dynamic skills of the individual are supported. Thereby, it is of great importance that intelligence games take place in the school environment. It is stated in the study of Demirel (2015) that if research on intelligence and mind games are evaluated in general terms, most of the intelligence games studied in are not associated with the learning outcomes of any lesson / subject area, and that there is a need of studies indicating which intelligence games support which lesson/subject learning outcomes.

It is thought that with new activities, materials and educational environment to be created in the Social Studies course, alternatives for concept teaching will increase, students will be active, and that education and training will improve productivity, skills and intelligence. For this reason, in the world today where technology, educational materials, education programs and curriculum are developed rapidly, the use of intelligence and mind games with many special features might be of help in Social Studies course. It can be reported that the absence of such a study in the field of social studies, points to the place of the research in the relevant body of literature.

\section{Games Applied in the Study}

The games used in the research process were developed by the researchers. The games developed are compatible with verbal intelligence and mind games category. Both games are played as group games. The games are designed to have fun during concept teaching. One of the games is Tik Tak Concept Game (Tik Tak Kavram Oyunu) and the other is Keep in Mind Game (Aklında Tut).

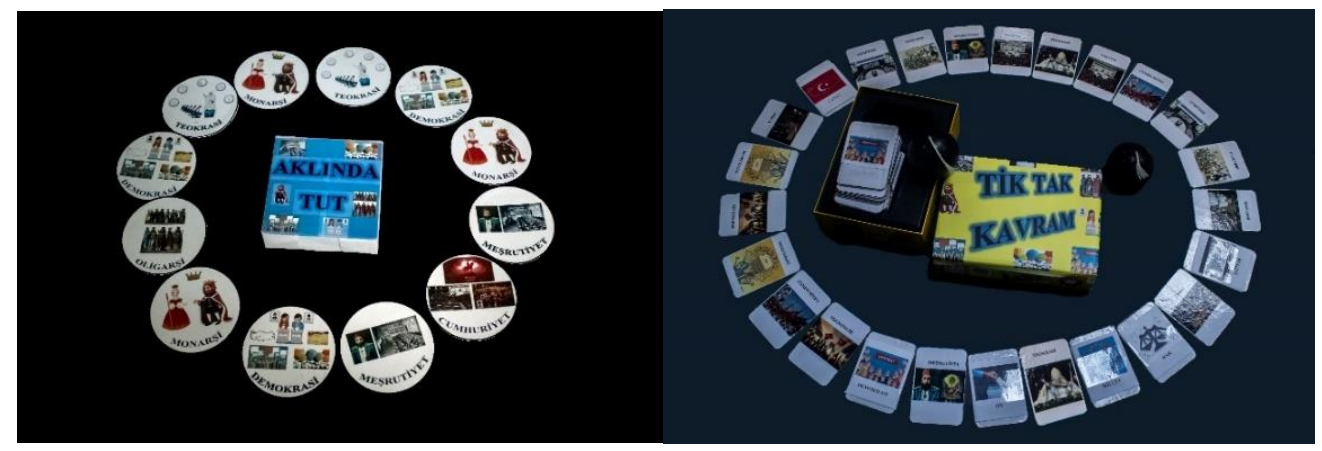

Figure 1. General Features of the Applied Games

It is known that the games used in the study are designed to conduct teaching concept. In the preparation process of the game:

- Playing cards have the quality to emerge concept association.

- The visuals on the playing cards respond to the level of concept recall.

- In addition to 12 concepts that are tried to be presented in the study, meaningful and permanent learning is aimed by including other concepts of Active Citizenship Learning Area.

- Both games include winners and losers. 
- The visuals on the cards of both games necessitate keeping short-term memory active. This situation is necessary for the rule that the individual cannot say a concept that is mentioned in the game process in the Tik Tak Concept game. That's why the individual should not forget the concepts already articulated during the game. In the 'Keep in Mind' game, if the individual can repeat the concepts that are said earlier, they can draw new cards and continue the game. These rules of the games are aimed at activating shortterm memory.

\section{Method}

\section{Model}

In line with the Social Studies Curriculum, a control group where the lesson is taught and an experimental group where the lesson is taught with intelligence and mind games are created neutrally from the existing classes. The study, in which no equalization between the groups was intended, is studied in the design of the " quasi-experimental with pre-test - posttest control group ". Experimental models are models in which the data planned to be observed directly under the control of the researchers are created and tested, the research objectives are mostly transferred by experiments and the results can be monitored in order to try to determine the cause-effect relationships (Karasar, 2005, 314). In the experimental group, the concepts in Active Citizenship Learning Area (Etkin Vatandaşlık Öğrenme Alanı) are taught with intelligence games while, in the control group, the learning area consists of teaching based on the 2018 Social Studies Curriculum. The aforementioned groups are determined randomly.

\section{The Population and Sample}

The sample group of the study consists of a total of 30 students in two classes, who are attending the 6th grade of a secondary school in Beylikdüzü district of Istanbul. The application was carried out in the second term of the 2018-2019 academic year. An experimental and a control group were determined by random selection (assignment) from the 6th grade classes in this primary school. It is the random assignment of the subjects to the experimental or control group (randomness) or the possibility of the subjects to be selected to any group. In so doing participants with equivalent characteristics could be selected (Gürbüz, Şahin, 2018, 376).

\section{Data Collection Instruments}

The data of the research is obtained by using two assessment instruments. Assessment instruments are achievement tests and attitude scales. In this sense, to assess the achievement levels, the KR-20 with reliability coefficient .89 and 0.56 average item difficulty, developed by Kürümlüoğlu (2019), is adapted and employed in this study. In order to determine the affective tendencies and attitude levels of the students, the Social Studies Lesson Attitude Scale, which was developed by Evin Gencel (2006), with an internal consistency coefficient of 0.95, is adapted and employed in the research. The attitude scale used in the research has 5 answering options. These are: 5-point Likert type scale with the options "Totally Agree", "Agree", " Neutral", "Disagree" and "Totally Disagree". 


\section{The Application Process}

Before moving to the Active Citizenship unit in the research, the Active Citizenship Learning Area Achievement Test and Social Studies Lesson Attitude Scale was applied as a pre-test to the experimental and control groups.

The implementation lasted five weeks (15 lessons). During the application, "Effective Citizenship Learning Area" was studied with the control group with the activities in the program consistent with the target behaviours and within the scope given to the teacher. With the experimental group, "Effective Citizenship" was carried out using intelligence games activities prepared while the learning area was being studied.

Application process consists of a total of 15 hours of application carried out for a total of 5 weeks. Subject processing covered a 12-hour process, while meeting students and applying the scales took 3 hours.

After the six-week application period, the same test and scale were re-applied to the experimental and control groups as post-test. In this way, it is aimed to determine whether there is a change or difference in both groups. Further, there was the opportunity to compare both groups.

\section{Data Collection and Data Analysis}

In the research, data were collected with two instruments. One of them is Achievement Test Regarding Social Studies Lesson Citizenship Learning Area (Sosyal Bilgiler Dersi Etkin Vatandaşlık Öğrenme Alanına İlişkin Başarı Testi) and the other one is Social Studies Lesson Attitude Scale (Sosyal Bilgiler Dersi Tutum Ölçeği). The results of the Shapiro-Wilk test are examined so as to determine the suitability of the assessments obtained from both scales to normal distribution. Apart from that, the ratio of skewness and kurtosis to error pursuant to normal distribution is examined.

A descriptive analysis of the corrected scores obtained from the achievement test and attitude scale performed before the experimental process is interpreted according to the mean and standard deviation values. In the analysis of the pre-test and post-test scores of the groups, Independent Samples t-Test analysis is performed. Nevertheless, analysis with Levene Test was performed primarily for the homogeneity of variances. If the data are normal and the variances are homogeneous, $t$ Test analysis is continued. If the data are not suitable for normal distribution and if the variances are not homogeneous, analysis is done with Mann Whitney U test. In the in-group comparison (control group pre-test-post-test; experimental group pre-test-post-test) dependent samples are analysed with the t-test. In the absence of a normal distribution, analysis is performed with the Wilcoxon Sign Test (Büyüköztürk, 2002; Özdamar, 2002).

In the case of a difference between the post-test scores of the experimental and control groups, the suitability of the data to the normal distribution and the homogeneity of the variances are analysed. By the same token, the dependency for all groups is tested with mutual regression curve for all groups. With this aim, the scatter plots are examined (Johnson and Wichern, 2007; Mertler and Vannatta, 2005; Tabachnick and Fidell, 2013). 


\section{Findings and Discussion}

\section{Results of the Descriptive Analysis}

Shapiro-Wilk test (Shapiro, Wilk, 1965) analysis is made regarding the descriptive analysis and normality distribution related to the pre-test and post-test scores of the experimental and control groups of Social Studies Lesson Effective Citizenship Learning Area Achievement Test. The results of the analysis are given in Table 1.

Table 1. Descriptive and Normality Analysis Results

\begin{tabular}{|c|c|c|c|c|c|c|c|}
\hline \multirow[b]{2}{*}{ Achievement Test } & \multirow{2}{*}{$\mathrm{N}$} & \multirow[b]{2}{*}{ Mean } & \multirow[b]{2}{*}{$\mathrm{SD}$} & \multirow[b]{2}{*}{ Skewness } & \multirow{2}{*}{ Kurtosis } & \multicolumn{2}{|c|}{ Shapiro-Wilk Statistic } \\
\hline & & & & & & Statistic & $\mathrm{p}$ \\
\hline Control Pre-test Success & 18 & 8.25 & 2.75 & .345 & -.361 & .891 & $.122 *$ \\
\hline Control Post-test Success & 18 & 16.40 & 5.61 & .249 & -1.133 & .915 & $.249 *$ \\
\hline $\begin{array}{l}\text { Experimental Pre-test } \\
\text { Success }\end{array}$ & & 12.89 & 5.30 & .628 & -1.113 & .874 & $.074 *$ \\
\hline $\begin{array}{l}\text { Experimental } \\
\text { Success }\end{array}$ & & 27.06 & 2.58 & -.050 & -1.330 & .943 & $.534 *$ \\
\hline
\end{tabular}

* p>.05; Standard Error for Skewness, Experimental= .637, Control=.536; Standard Error for Kurtosis Experimental=1.232, Control $=1.038$

According to the results of the analysis, as a result of the achievement test of the Social Studies Course Effective Citizenship Learning Area of the students, the Control Group pre-test mean score $($ Mean $=8.25, \mathrm{SD}=2.75)$ is very low. Experimental Group pre-test success mean (Mean= $12.89, \mathrm{SD}=5.30$ ) is also low. Students' level of knowledge on the subject is not high. The control group post-test mean score (Mean $=16.40, \mathrm{SD}=5.61)$ is at the intermediate level. This indicates that the success level of the activities currently envisaged in the program is not high, although they have increased in success.

Regarding the compliance of the data with the normality assumption, Shapiro-Wilk analysis is carried out as the group numbers are below 50 (Mertler and Vannatta, 2005). Plus, it is examined whether the skewness and kurtosis coefficients are within the \pm 2 ratio of error (Tabachnick, Fidell, 2013; McKillup, 2012). As a result of the Shapiro-Wilk analysis, it is observed that both the Control Group's pre-test ( $\mathrm{S}-\mathrm{W}=.891, \mathrm{p}>.05)$ and the Control Group's post-test ( $\mathrm{S}-\mathrm{W}=.915, \mathrm{p}>.05)$ are not significant. It is detected that the experimental group's pre-test $(\mathrm{S}-\mathrm{W}=.874, \mathrm{p}>.05)$ and the experimental group's post-test $(\mathrm{S}-\mathrm{W}=.943, \mathrm{p}>.05)$ scores are not significant. Aside from that, Skewness / Standard error and kurtosis / Standard error values are observed to be close to 0 .

\section{Analysis Result for the Experimental and Control Group Pre-test Achievement Scores}

The problem of the research is determined as "Is there a significant difference between the pre-test scores of the Experimental and Control Groups?". So as to answer the research question, analysis is conducted the Independent Samples t Test. Analysis results are given in Table 2.

Table 2. Independent Samples t Test Analysis Result for Experimental and Control Group Pretest Achievement Scores

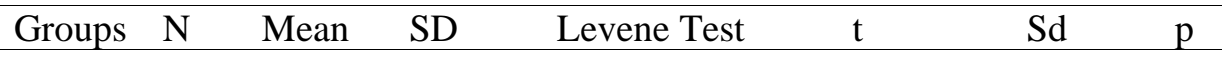




\begin{tabular}{|c|c|c|c|c|c|c|c|c|}
\hline \multicolumn{4}{|c|}{$\begin{array}{l}\text { Achievemen } \\
\text { t Test }\end{array}$} & \multirow{3}{*}{$\begin{array}{l}\mathrm{F} \\
-8.555\end{array}$} & \multicolumn{4}{|l|}{$\mathrm{p}$} \\
\hline & Control 18 & 8.25 & 2.75 & & & & & \\
\hline Pre-test & Experime $_{12}$ & 12.89 & 5.30 & & $.007 *$ & -2.793 & 14.978 & $.014^{*}$ \\
\hline
\end{tabular}

As a result of the analysis, since the assessments are conformable to the normality assumption (Table 1) but the variances are not homogeneous (Levene Test $F=8.555, \mathrm{p}<.05$ ), the $t$ value in which variances are not equal and the degree of freedom are taken into account (Ross and Willson, 2004). Accordingly, the control group's pre-test mean (Mean $=8.25, \mathrm{SD}=2.75$ ) is observed to be lower $(\mathrm{t}=-2.793, \mathrm{p}<.05)$ than the experimental group's pre-test mean $(\mathrm{Mean}=$ $12.89, \mathrm{SD}=5.30$ ). This shows that there is a difference between the mean scores of the groups before starting the experimental process.

\section{Analysis Results of Control Group Pre-test and Post-test Achievement Scores}

The research problem is determined as "Is there a significant difference between the pre-test and post-test scores of the Control Group?". So as to seek an answer to the research question, analysis is conducted the Dependent Samples t Test. Analysis results are given in Table 3.

Table 3. Analysis of Dependent Samples t-Test Results related to Pre-test and Post-test Scores of Control Group

\begin{tabular}{|c|c|c|c|c|c|c|c|c|c|}
\hline \multirow{2}{*}{ Group } & \multirow{2}{*}{ Test } & \multirow{2}{*}{$\mathrm{N}$} & \multirow{2}{*}{ mean } & \multirow{2}{*}{ SD } & \multicolumn{2}{|c|}{ Correlation } & \multirow[b]{2}{*}{$-\mathrm{t}$} & \multirow{2}{*}{ sd } & \multirow[b]{2}{*}{$\mathrm{p}$} \\
\hline & & & & & $\mathrm{r}$ & $p$ & & & \\
\hline Control & $\frac{\text { Pre-test }}{\text { Post-test }}$ & $\begin{array}{l}18 \\
18\end{array}$ & $\begin{array}{l}8.25 \\
16.40\end{array}$ & $\begin{array}{l}2.75 \\
5.61\end{array}$ & -.77 & $.000^{*}$ & -8.810 & 17 & $.000^{*}$ \\
\hline
\end{tabular}

$* \mathrm{p}<.05$

As a result of the dependent samples t-test analysis, there is a significant difference in favour of the post-test $(\mathrm{t}=-8.810, \mathrm{p}<.05)$ between the pre-test mean $($ Mean $=8.25, \mathrm{SD}=2.75)$ of the control group and its post-test mean scores (Mean $=16.40, \mathrm{SD}=5.61$ ). The results of the analysis exhibit that the method applied in the control group has a significant effect on student success. It is normal and expected that the implementation of the activities envisaged in the official program will also have a significant impact on success.

\section{Analysis Results of Experimental Group Pre-test and Post-test Achievement Scores}

The research problem is determined as "Is there a significant difference between the pre-test and post-test scores of the Experimental Group?". So as to search for an answer to the research question, analysis is conducted the Dependent Samples t Test. Analysis results are given in Table 4.

Table 4. Analysis of Dependent Samples t-Test Results related to Pre-test and Post-test Scores of Experimental Group

\begin{tabular}{|c|c|c|c|c|c|c|c|c|c|}
\hline \multirow{2}{*}{ Group } & \multirow{2}{*}{ Test } & \multirow{2}{*}{$\mathrm{N}$} & \multirow{2}{*}{ Mean } & \multirow{2}{*}{ SD } & \multicolumn{2}{|c|}{ Correlation } & \multirow[b]{2}{*}{$-\mathrm{t}$} & \multirow{2}{*}{ sd } & \multirow[b]{2}{*}{$\mathrm{p}$} \\
\hline & & & & & $\mathrm{r}$ & $\mathrm{p}$ & & & \\
\hline Experimer & Pre-test & 12 & 12.89 & 5.30 & -74 & $.006 *$ & -10.481 & 11 & $.000 *$ \\
\hline tal & Post-test & 12 & 27.06 & 2.58 & & & & & .000 \\
\hline
\end{tabular}


As a result of the dependent samples t-test analysis, there is a significant difference in favour of the post-test $(\mathrm{t}=-10.481, \mathrm{p}<.05)$ between the pre-test mean (Mean=12.89, $\mathrm{SD}=5.30)$ of the experimental group and its post-test mean scores (Mean $=27.06, \mathrm{SD}=2.58$ ).

\section{Analysis Result for the Experimental and Control Group Post-test Achievement Scores}

The research problem is determined as "Is there a significant difference between the post-test scores of the Experimental and Control Groups?". So as to answer the research question, analysis is conducted the Independent Samples t Test. Analysis results are given in Table 5.

Table 5. Analysis of Independent Samples t-Test Results related to the Post-test Scores of Experimental and Control Groups

\begin{tabular}{lllllllll}
\hline $\begin{array}{l}\text { Achievement } \\
\text { Test }\end{array}$ & Groups N & Mean & SD & \multicolumn{2}{l}{ Levene Test } & t & sd & $\mathrm{p}$ \\
\hline Post-test & Control 18 & 16.40 & 5.61 & & $\mathrm{p}$ & & \\
& $\begin{array}{l}\text { Experi } \\
\text { mental }\end{array}$ & 27.06 & 2.58 & 7.140 & $.012^{*}$ & -7.028 & 25.512 & $.000^{*}$ \\
\hline
\end{tabular}

$* \mathrm{p}<.05$

As a result of the analysis, since the assessments are in concert with the normality assumption (Table 1) yet the variances are not homogeneous (Levene Test $F=7.140, \mathrm{p}<.05$ ), the $t$ value and the degree of freedom in which variances are not equal are taken into consideration (Ross and Willson, 2004). In that event, the control group's post-test mean (Mean $=16.40, \mathrm{SD}=5.61$ ) is observed to be lower $(\mathrm{t}=-7.028, \mathrm{p}<.05)$ than the experimental group's post-test mean (Mean $=$ $27.06, \mathrm{SD}=2.58$ ). The results of the analysis show that the method applied in the experimental group increases the student success even more. Nonetheless, as there is a significant difference between the pre-test scores, when the pre-test scores are kept constant by conducting Covariance analysis (Ancova) it is checked whether there is a significant difference between post-test scores. The results of the analysis are presented in Table 6.

Table 6. The Results of the Ancova Analysis

\begin{tabular}{|c|c|c|c|c|c|c|c|}
\hline & Type I: Sum & of & & & & Partial & Eta \\
\hline Source of Variance & Square & sd & Mean Square & $\mathrm{F}$ & $\mathrm{p}$ & Squared & \\
\hline Corrected Model & $986.246 a$ & 2 & 493.123 & 30.285 & $.000^{*}$ & .692 & \\
\hline Intercept & 12809.211 & 1 & 12809.211 & 786.673 & $.000 *$ & .967 & \\
\hline Pre-test & 664.366 & 1 & 664.366 & 40.802 & $.000 *$ & .602 & \\
\hline $\begin{array}{l}\text { Group(Experimental- } \\
\text { Control) }\end{array}$ & 321.880 & 1 & 321.880 & 19.768 & $.000 *$ & .423 & \\
\hline Error & 439.635 & 27 & 16.283 & & & & \\
\hline Total & 14235.092 & 30 & & & & & \\
\hline
\end{tabular}

a. $R^{2}==.692$ (Corrected $\left.R^{2}=.669\right)$, (Levene Test $\left.\mathrm{F}(1,28)=3.880, \mathrm{p}=0.59\right),{ }^{*} \mathrm{p}<.05$

As a result of the covariance analysis, there is a statistically significant difference between the post-test scores of the Experimental and Control Groups $(F=40.802, p<.05)$. The results of the analysis reflect that when the students' pre-test achievement scores are examined, there is a significant difference between the post-test scores in favour of the experimental group. In other words, it can be said that the method applied in the Experimental Group increases the achievement even more than the method applied in the Control Group. The effect size shows that the difference is important and is not caused by TYPE I error. 


\subsection{Results Regarding the Attitude}

Under this title, the findings obtained from the analysis of the scores obtained from the attitude scale in the research are included. In the Control and Experimental Groups, the Attitude Scale for Social Studies Lesson is applied to both groups before the procedure. Learning-teaching activities in the Active Citizenship Learning Area, implemented in the 2018 Social Studies Curriculum, are applied to the Control Group. In the experimental group, after teaching with activities based on intelligence and mind games, the Attitude Scale for Social Studies Lesson applied as the pre-test is reapplied as a post-test.

\subsubsection{Results of the Descriptive Analysis}

Descriptive analysis is conducted to determine the attitudes of students in the experimental and control groups for the Social Studies course. In addition to that, Shapiro-Wilk analysis is performed to see whether the scores have normal distribution (Mertler and Vannatta, 2005). It is also checked whether the skewness and kurtosis coefficients are within the error ratio \pm 2 (Tabachnick, Fidell, 2013; McKillup, 2012). The results of the analysis are shared in the Table 13.

Table 7. Descriptive and Normality Analysis Results

\begin{tabular}{llllllll}
\hline Attitude Scale & $\mathrm{N}$ & Mean & $\mathrm{SD}$ & \multirow{2}{*}{ Skewness } & \multirow{2}{*}{ Kurtosis } & \multicolumn{2}{l}{ Shapiro-Wilk } \\
\hline Control pre-test & 18 & 2.90 & .49 & -.203 & 1.000 & .947 & $.57^{*}$ \\
$\begin{array}{l}\text { Control post-test } \\
\text { Experimental pre- }\end{array}{ }^{*} 12$ & 3.13 & .57 & .362 & 1.399 & .891 & $.120^{*}$ \\
$\begin{array}{l}\text { test } \\
\begin{array}{l}\text { Experimental post- } \\
\text { test }\end{array}\end{array}$ & 3.79 & .66 & -.655 & -.368 & .943 & $.533^{*}$ \\
\hline
\end{tabular}

* p>.05; Standard Error for Skewness, Experimental= .637, Control=.536; Standard Error for Kurtosis Experimental=1.232, Control $=1.038$

According to the results of the analysis, the mean of the Control Group (Mean $=2.90, \mathrm{SD}=$ .49) of the scores obtained from the Attitude Scale applied as a pre-test for the Social Studies Course is negative. The mean of the attitude scores obtained from the pre-test application of the Experimental Group (Mean $=2.79, \mathrm{SD}=.66$ ) is also low. Although the mean of the scores of the Control Group (Mean $=3.13, \mathrm{SD}=.57$ ) increased from the Attitude Scale applied as a result of the instruction as a post-test, the mean is negative. The mean score of the experimental group students' attitude scale applied as a post-test (Mean $=3.56, \mathrm{SD}=.29$ ) is positive. The results of the analysis denote that there is an increase in the scores of Attitude Scale for Social Studies Lesson applied following the teaching-learning procedure both in control and experimental groups, compared to the scores obtained at the beginning of the learning and teaching process. This shows that the mean of the attitudes of the experimental group students is positive.

As a result of the Shapiro-Wilk analysis, both the Control Group pre-application attitude scale scores $(\mathrm{SW}=.947, \mathrm{p}>.05)$ and the Control Group's attitude scale scores $(\mathrm{SW}=.891, \mathrm{p}$ > $.05)$ are found to be significant. It is observed that the Attitude Scale pre-application ( $\mathrm{S}-\mathrm{W}=$ $.943, \mathrm{p}>$.05) scores of the Experimental Group and the scores of Experimental Group's Attitude Scale applied as a post-application $(\mathrm{S}-\mathrm{W}=.953, \mathrm{p}>.05)$ are not significant. Besides, Skewness / Standard Error and Kurtosis / Standard Error rates are observed to be below \pm 2 points. Accordingly, it is observed that the pre-application - post-application scores of experimental and control groups in the Attitude Scale show normal distribution. 


\subsubsection{Independent Samples t Test Analysis Result for Experimental and Control Group}

\section{Pre- application Attitude Scores}

The research problem is determined as "Is there a significant difference between the preapplication attitude scores of the Experimental and Control Group students?". So as to answer the research question, analysis is conducted the Independent Samples t Test. Analysis results are given in Table 8 .

Table 8: Independent Samples t Test Analysis Result for Experimental and Control Group Preapplication Attitude Scores

\begin{tabular}{|c|c|c|c|c|c|c|c|c|c|}
\hline \multirow{2}{*}{\multicolumn{2}{|c|}{ Attitude TestGroups }} & \multirow{2}{*}{$\mathrm{N}$} & \multirow{2}{*}{ Mean } & \multirow{2}{*}{ SD } & \multicolumn{2}{|c|}{ Levene Test } & \multirow[b]{2}{*}{ t } & \multirow{2}{*}{$\mathrm{Sd}$} & \multirow{2}{*}{$\mathrm{p}$} \\
\hline & & & & & $\bar{F}$ & $\mathrm{p}$ & & & \\
\hline \multirow[b]{2}{*}{ Pre-test } & Control & 18 & 2.90 & .48 & & & & & \\
\hline & $\begin{array}{l}\text { Experime } \\
\mathrm{nt}\end{array}$ & $e_{12}$ & 2.77 & .66 & 1.778 & $.193^{*}$ & .535 & 28 & $.597 *$ \\
\hline
\end{tabular}

$* \mathrm{p}>.05$

As a result of the analysis, since assessments are in accordance with the normality assumption (Table 7) and the variances are homogeneous (Levene Test $F=1.778, p>.05$ ), the $t$ value and the degree of freedom that the variances are equal (Ross and Willson, 2004) are taken into account. At the end of the Independent $t$ Test analysis, not a significant difference is spotted $(\mathrm{t}=.535, \mathrm{p}<.05)$ between Control Group's attitude scale pre-application mean scores (Mean= 2.90, $\mathrm{SD}=.48$ ) and Experimental Group's attitude scale pre- application mean scores (Mean=2.77, $\mathrm{SD}=.66$ ). Analysis results signify that there is no difference between the mean scores of the groups before starting the experimental process. The fact that there is no difference between the scores obtained from the pre-application of the attitude scale facilitated the comparison in the post-tests.

\subsubsection{Analysis Results of Control Group Pre-application and Post-application Attitude}

\section{Scale Scores}

The research problem is determined as "Is there a significant difference between the preapplication and post- application attitude scale scores of the Control Group?". So as to answer the research question, analysis is conducted for the Dependent Samples t Test. Analysis results are provided in Table 9.

Table 9. Analysis of Dependent Samples t-Test Results related to Pre- application and Postapplication Attitude Scale Scores of Control Group

\begin{tabular}{|c|c|c|c|c|c|c|c|c|c|}
\hline \multirow{2}{*}{ Group } & \multirow{2}{*}{\multicolumn{2}{|c|}{$\begin{array}{l}\text { Applicatio } \\
\mathrm{n}\end{array}$}} & \multirow{2}{*}{ mean } & \multirow{2}{*}{ SD } & \multicolumn{2}{|c|}{ Correlation } & \multirow[b]{2}{*}{$\mathrm{t}$} & \multirow{2}{*}{ sd } & \multirow{2}{*}{$\mathrm{p}$} \\
\hline & & & & & $\mathrm{r}$ & $\mathrm{p}$ & & & \\
\hline \multirow{2}{*}{ Control } & Pre & 18 & 2.90 & .49 & \multirow{2}{*}{-.82} & \multirow{2}{*}{$.000 *$} & \multirow{2}{*}{-2.955} & \multirow{2}{*}{17} & \multirow{2}{*}{$.009 *$} \\
\hline & Post & 18 & 3.13 & .57 & & & & & \\
\hline
\end{tabular}

$* \mathrm{p}<.05$

As a result of the dependent samples t-test analysis, there is a significant difference in favour of the post- application ( $\mathrm{t}=-2.955, \mathrm{p}<.05$ ) between the pre- application mean (Mean $=2.90$, SD $=.49$ ) of the control group and its post- application mean scores (Mean $=3.13, \mathrm{SD}=.57)$. The results of the analysis show that the method applied in the control group has a significant effect on students' attitudes. It is normal and expected that the implementation of the activities envisaged in the official program will also have a significant impact on attitude. 


\subsubsection{Analysis Results of Experimental Group Pre-application and Post-application}

\section{Attitude Scale Scores}

The research problem is determined as "Is there a significant difference between the preapplication and post- application attitude scale scores of the Experimental Group?". So as to answer the research question, analysis is run for the Dependent Samples t Test. Analysis results are given in Table 10.

Table 10. Analysis of Dependent Samples t-Test Results related to Pre- application and Postapplication Scores of Experimental Group

\begin{tabular}{|c|c|c|c|c|c|c|c|c|c|}
\hline \multirow{2}{*}{ Group } & \multirow{2}{*}{$\begin{array}{l}\text { Applicatio } \\
\mathrm{n}\end{array}$} & \multirow{2}{*}{$\mathrm{N}$} & \multirow{2}{*}{ Mean } & \multirow{2}{*}{ SD } & \multicolumn{2}{|c|}{ Correlation } & \multirow[b]{2}{*}{$-\mathrm{t}$} & \multirow{2}{*}{ sd } & \multirow[b]{2}{*}{$\mathrm{p}$} \\
\hline & & & & & $\mathrm{r}$ & $\mathrm{p}$ & & & \\
\hline \multicolumn{2}{|c|}{ Experimen Pre } & 12 & 2.77 & .66 & -63 & 020* & 5017 & 11 & $000 *$ \\
\hline tal & Post & 12 & 3.56 & .29 & .03 & $.029^{\circ}$ & -5.017 & 11 & .000 \\
\hline
\end{tabular}

As a result of the dependent samples t-test analysis, there is a significant difference in favour of the post-application $(\mathrm{t}=-4.109, \mathrm{p}<.05)$ between the pre-test mean $(\mathrm{Mean}=2.77, \mathrm{SD}=.66)$ of the experimental group and its post- application mean scores (Mean $=3.56, \mathrm{SD}=.29$ ). The results of the analysis show that the method applied in the experimental group has a significant effect on student achievement. That being said, the low correlation suggests that the effect on students' attitudes is not the same. While some students' attitudes have increased, others have not increased evenly. In particular, the low standard deviation can be interpreted as the attitudes of those with low attitudes increase, whereas those with high and positive attitudes do not increase much.

\subsubsection{Analysis Result for the Experimental and Control Group Post-application}

\section{Attitude Scale Scores}

The research problem is determined as "Is there a significant difference between the postapplication scores of the Experimental and Control Groups?". So as to answer the research question, analysis is conducted for the Independent Samples t Test. Analysis results are given in Table 11.

Table 11. Analysis of Independent Samples t-Test Results related to the Post-application Scores of Experimental and Control Groups

\begin{tabular}{|c|c|c|c|c|c|c|c|c|c|}
\hline \multirow{2}{*}{$\begin{array}{l}\text { Attitude } \\
\text { scale }\end{array}$} & \multirow{2}{*}{ Groups } & \multirow{2}{*}{$\mathrm{N}$} & \multirow{2}{*}{ Mean } & \multirow{2}{*}{ SD } & \multicolumn{2}{|c|}{ Levene Test } & \multirow[b]{2}{*}{$-\mathrm{t}$} & \multirow{2}{*}{ sd } & \multirow[b]{2}{*}{$\mathrm{p}$} \\
\hline & & & & & $\bar{F}$ & $p$ & & & \\
\hline \multirow[b]{2}{*}{$\begin{array}{l}\text { Post- } \\
\text { applicatior }\end{array}$} & Control & 18 & 3.13 & .57 & \multirow{2}{*}{2.061} & \multirow[b]{2}{*}{$.162 *$} & \multirow[b]{2}{*}{-2.411} & \multirow[b]{2}{*}{28} & \multirow[b]{2}{*}{$.023 * *$} \\
\hline & $\begin{array}{l}\text { Experimen } \\
\text { tal }\end{array}$ & 12 & 3.56 & .29 & & & & & \\
\hline
\end{tabular}

$$
* p>.05, * * p<.05
$$

As a result of the analysis, since the assessments are in accordance with the normality assumption (Table 1) yet the variances are homogeneous (Levene Test F=2.061, p>.05), the $t$ value and the degree of freedom in which variances are equal are taken into consideration (Ross and Willson, 2004). A significant difference is found in favour of the control group $(t=-2.411$, $\mathrm{p}<.05)$ between the control group's post-application mean (Mean $=3.13, \mathrm{SD}=.57$ ) and the experimental group's post-application mean (Mean $=3.56, \mathrm{SD}=.29)$. The results of the analysis represent that the method applied in the experimental group increases the students' attitude even 
more. However, that there is no significant difference between the pre-application attitude scores, but that there is a significant difference between the scores in the post-application means that the method applied in the experimental group is effective in increasing the attitudes. Covariance analysis is conducted to determine whether the difference between the mean scores of the Experiment and Control Group attitude is caused by the pre-test scores. By conducting Covariance analysis (Ancova) it is analysed if there is a significant difference between post-test scores when the pre-test scores are kept constant. The results of the analysis are presented in Table 12.

Table 12. The Results of the Ancova Analysis

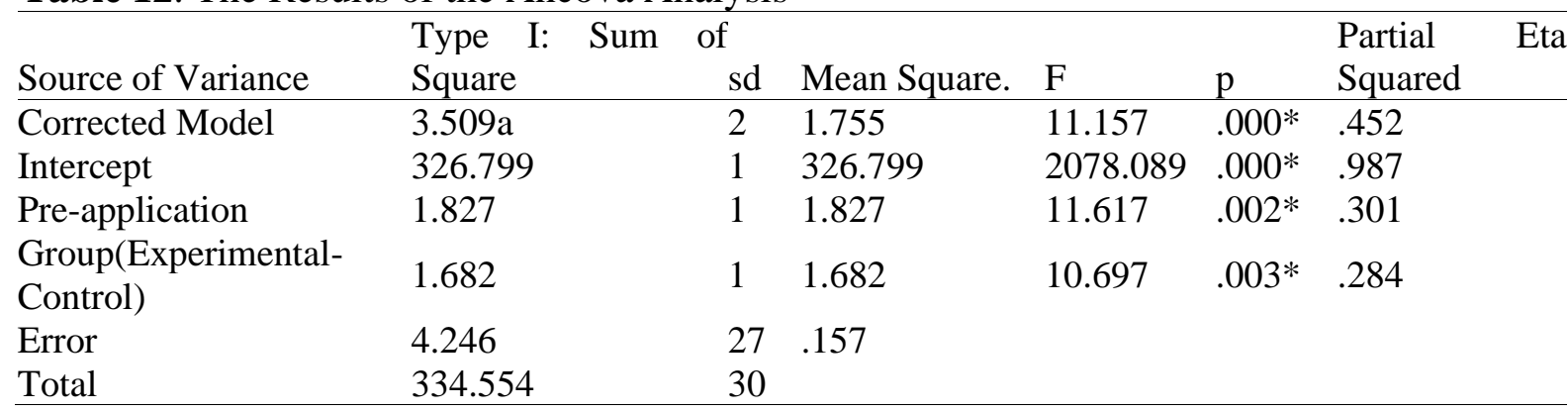

a. $R^{2}==.452\left(\right.$ Corrected $\left.R^{2}=.412\right),($ Levene Test $\mathrm{F}(1,28)=.060, \mathrm{p}=0.809) * \mathrm{p}<.05$

As a result of the covariance analysis, there is a statistically significant difference between the post-application attitude scores of the Experimental and Control Groups $(\mathrm{F}=10.697, \mathrm{p}<.05)$. The results of the analysis show that when the students' pre-test achievement scores are examined, there is a significant difference between the post-test scores in favour of the experimental group. In other words, it can be said that the method applied in the Experimental Group increases the achievement even more than the method applied in the Control Group. The effect size shows that the difference is important and is not caused by TYPE I error.

\section{Results and Discussion}

When the findings of the research are evaluated in general, it has been observed that teaching with intelligence and mind games significantly increases students' achievement compared to the activities envisaged in the current program. The increase in student achievement can be explained by the fact that the method applied in the experimental group is suitable for the nature of the student and that they learn by being both mentally and physically active whilst having fun. That it is designed as a teaching activity suitable for the students' age and developmental characteristics in the experimental group is among the factors making it effective. On the other hand, the positive change in the attitudes of the students is an evidence of the fact that the method applied in the experimental group is more successful than the activities proposed in the current program. It is also worth announcing that the teaching in the control group where the current program is applied has a significant change in terms of both success and attitude. Naturally, students learn an unfamiliar topic, which will lead to an increase in success. A positive change in attitudes is also important for the current program. Teaching based on intelligence and mind games in the teaching of concepts related to Effective Citizenship Learning Area would help students both enjoy the lesson and increase their success.

Attitude results show that teaching based on intelligence and mind games is more effective than teaching based on the activities envisaged in the current program. It is observed that the attitudes 
of the students towards the Social Studies course are positive in the post-test of experimental group. That students have positive attitude towards an object, situation or event is expected to have a positive effect on their achievement. A similar result is reached by Y1lmaz (2019) that the effects of intelligence games on reasoning skills and attitudes towards mathematics in mathematics lesson create changes in students' views on mathematics. In the interview form, it was observed that the students developed positive attitudes towards mathematics through the intelligence games, the games had positive changes in the individual's math anxiety, and there were positive changes in their emotional abilities as well as in their feelings and thoughts. Demirel (2015) reaches the conclusion that intelligence games support students in terms of gaining positive attitude towards the activities and the lesson, in the study entitled evaluating the cognitive and affective effects of using intelligence games in Turkish and mathematics lessons. When the literature is examined, it is seen that teachers and students develop positive attitudes towards intelligence games in similar studies, and there is an increase in the motivation of the students during the lessons (Devecioğlu, Karadağ, 2014; Kurbal, 2015). In her study, Sadıkoğlu (2017) concluded that intelligence games have positive effects on interpersonal relationships, resulting in an increase in the awareness of national and universal values, and improve student autonomy, and that the use of intelligence games in values education is also effective. In addition, the rules of some of the intelligence games are difficult for some students and it was demonstrated through studies that this would create negative motivation during the course (Hidıroğlu, 2014). This shows the necessity of effective classroom management. In their studies, Sungur and Güngören (2009) state that the perception of the classroom environment affects the motivation of the students and determines the participation levels of the students in the course. That students learn through a student-centred but a more enjoyable activity just as in a teaching environment based on intelligence and mind games in the current program-based practices, provides an educational activity that suits their nature. It is also possible that intelligence and mind games make students feel more comfortable and become entertained in the lesson. It is a supportive situation that students' both achievements and attitudes have increased in the experimental group.

It is observed in the research that intelligence and mind games increase the success in concept teaching in the Social Studies course. The importance of concept teaching regarding Social Studies was stressed in related studies of the literature. Soylu (2019) states that concept teaching in Social Studies contributes directly to the effective learning process, makes learning permanent, helps abstract concepts become tangible and the subject more understandable, supports communication, is supportive in reasoning, and that Social Studies is rich in terms of concept teaching. In her study, Tural (2011) alleges that activities and practices developed with a constructivist approach support permanence in students' 'learning, increase their success based on the answers given by students to the application, that different activities and applications are needed for students' learning needs, and lastly that especially student-centred applications should be supported in concept teaching.

The future of countries depends on the level of education they offer to its citizens. Considering this issue, the quality of education would be comprehended. For this reason, educators are required to do their best in searching qualified practices when training their learners. This is one of the basic duties of educators (Oruç, 2006, 85). Just like concentrating upon effective teaching techniques and methods in education, the environments in which these methods and techniques are to be applied and the educational materials to be used during application are important. Thence, the fact that educators support educational environments with remarkable and educational materials would consequently brighten the future of the country. It is thought that intelligence and mind games should be among the basic tools to warrant this. 


\section{Suggestions}

- Studies examining the effect of intelligence and mind games on participants' attitudes towards academic achievement and Social Studies lesson regarding the demographic characteristics of the participants are recommended.

- This study was carried out with a sample group of 30 students and it was carried out with the participation of 6th grade students. New research can be done with students of different grades.

- In line with this research, in which intelligence games are determined to be an effective tool in the teaching of the concepts of Social Studies lesson, studies can be conducted on the impact of intelligence and mind games in values education in social studies lesson and in teaching different subjects of the course.

- Two verbal intelligence games have been developed by the researchers to be used in this research. Verbal intelligence games developed according to the lesson content to be used in teaching verbal situations such as concept teaching can be developed.

- The Tik Tak Concept (Tik Tak Kavram) and Keep in Mind (Aklında Tut) games designed within the scope of this research can be used for the teaching of the concepts of mathematics, science, Turkish, geography, history and foreign language, as well as the concepts of almost all disciplines of social sciences.

\section{References}

Adalar, H., \& Yüksel, İ. (2017). Sosyal bilgiler, fen bilimleri ve diğer branş öğretmenlerinin görüşleri açısından zekâ oyunları öğretim programı. [Intelligence games currıculum from social studies, science and other branch teachers' point of view]. Electronic Turkish Studies. 12(28), 1-24

Bottino, R. M., \& Ott, M. (2006). Mind games, reasoning skills and the primary school curriculum. Learning Media and Technology. 31(4), 359-375.

Büyüköztürk, Ş. (2002). Sosyal bilimler için veri ve analizi el kitabı: istatistik, araştırma deseni, SPSS uygulamalarl ve yorum. [Data and analysis handbook for social sciences: statistics, research pattern, SPSS applications and interpretation]. Ankara: Pegem Academy Publishing.

Çalışkan, N., \& Karadağ, E. (2014). Ĕ̈itimde drama teorik temelleri ve uygulama örnekleri. [Drama theoretical foundations and practice examples in education]. Refurbished 3. Bs. Ankara: Anı Publishing.

Demirel, T. (2015). Zekâ oyunlarının Türkçe ve Matematik derslerinde kullanılmasının ortaokul ögrencileri üzerindeki bilişsel ve duyuşsal etkilerinin değerlendirilmesi. (Unpublished Doctoral Dissertation). Atatürk University Institute of Educational Sciences.

Devecioğlu, Y.\& Karadağ, Z. (2014). Amaç, beklenti ve öneriler bağlamında zekâ oyunları dersinin değerlendirilmesi. [Evaluation of mind puzzle course at the context of goals, expectations and recommendations]. Journal of Bayburt University Faculty of Education. IX (I), 41-61.

Erden, M. (Undated). Sosyal bilgiler ögretimi. [Social studies teaching]. Istanbul: Alkım Publishing.

Evin Gencel, İ. (2006). Örenme stilleri, deneyimsel öğrenme kuramına dayalı eğitim, tutum ve sosyal bilgiler program hedeflerine erişi düzeyi. [Learning styles, instruction based on Kolb's experential learning theory, attitude and social studies achievement]. (Unpublished Doctoral Dissertation). Dokuz Eylül University Institute of Educational Sciences. 
Gardner, H., Thomas, E., \& Hatch, C. (1990). Multiple intelligences go to school: Educational implications of the theory of multiple intelligences. CTE Technical Report. Issue No. 4

Griffiths, M. D. (1996). Computer game playing in children and adolescents: A review of the literature. In Tim Gill. (Eds)., Electronic children: How children are responding to the information revolution (41-58). London: National Children's Bureau.

Gürbüz, S., \& Şahin, F. (2018). Sosyal bilimlerde araştırma yöntemleri. [Research methods in social sciences]. 5. bs. Ankara: Seçkin Publishing.

Gürgil, F. (2011). İlköğretim sosyal bilgiler programında halk kültürünün yeri: ilköğretim öğrencilerinin halk kültürü dersi uygulamalarına ilişkin görüşleri. [The position of folk culture in the program of primary education social studies:the views of primary education students towards folk culture approach]. (Unpublished Master's Thesis). Gazi University Institute of Educational Sciences.

Hidıroğlu, F. M. (2014). The role of perceived classroom goal structures, self-efficacy, and student engagement in seventh grade students' science achievement. (Unpublished Master's Thesis), Middle East Technical University.

İlhan, G. O. 2016. Sosyal bilgiler öğretiminde çizgi romanların kullanımı. [The use of comics in social studies education] (Unpublished Doctoral Thesis). Afyon Kocatepe University Institute of Social Sciences.

Johnson, R. A.,\& Dean, W. W. (2007). Applied multivariate statistical analysis (Sixth Edition). United States: Pearson Education, Inc.

Karasar, N. 2005. Bilimsel araştırma yöntemi. [Scientific research method]. Nobel Publishing

Koçyiğit, S., Tuğluk, M. N., \& Kök, M. (2007). Çocuğun gelişim sürecinde eğitsel bir etkinlik olarak oyun. [Play as educational activtiy in the child's development process]. Journal of Kâzım Karabekir Education Faculty. 16: 324-342.

Köksal, M. S. (2006). Kavram öğretimi ve çoklu zekâ teorisi. [Concept teaching and multiple intelligences theory]. Kastamonu Education Journal, 14(2), 473-480.

Kurbal, M. S. (2015). An investigation of sixth grade students' problem solving strategies and underlying reasoning in the context of a course on general puzzles and games. (Unpublished Master's Thesis). Middle East Technical University.

Kürümlüoğlu, M. (2019). 6. Sınıf sosyal bilgiler dersi demokrasinin serüveni ünitesindeki kavram yanılgılarını giderme: Bir eylem araştırması. [Eliminating the misconception on the 6th grade social studies in the unit adventure of democracy': An action research]. (Unpublished Master's Thesis). Kırşehir Ahi Evran University Institute of Social Sciences.

Marangoz, D. (2018). Mekanik zeka oyunlarının ilkokul 2. sınıf öğrencilerinin zihinsel beceri düzeylerine etkisi. [The effect of mechanical mind games on mental skill levels of primary school second grade students]. Sakarya University, Institute of Educational Sciences

Marangoz, D., \& Demirtaş, Z. (2017). Mekanik zekâ oyunlarının ilkokul 2. sınıf öğrencilerinin zihinsel beceri düzeylerine etkisi. [The effect of mechanical mind games on mental skill levels of primary school second grade students]. The Journal of International Social Research, 10(53), 612-621.

McKillup, S. (2012). Statistics explained: An introductory guide for life scientists. second edition. United States: Cambridge University Press.

MEB. (2018). Sosyal bilgiler dersi ögretim programı. [Social studies course curriculum]. Ankara. MEB.

MEB. Eğitim vizyonu. [Education vision]. http://2023vizyonu.meb.gov.tr/doc/2023_EGITIM_VIZYONU.pdf 
MEGEP. (2009). Meslekî eğitim ve ögrretim sistemini güçlendirilmesi projesi, [Strengthening the vocational education and training system project]. Child Development and Education: Game Activity 1. Ankara, 2009.

Mertler, C. A., \& Vannatta. R. A. (2005). Advanced and multivariate statistical methods: Practical application and interpretation (Third Edition). United States: Pyrczak Publishing.

Metiner, E. (2018). Oyun dăgarcı̆̆ını geliştirme-I çocuk ve oyun. [Developing Game Vocabulary- I Child and Game]. Publication of Atatürk University Open Education Faculty. https://www.ataaof.com/upload/files/2018/09/PqlEHA8tHjcKNNE2LB51_29_e3b2d8 bdf7a23bd98a67a5411cf0aba8_file.pdf [19.12.2019]

Oruç, Ş. (2006). Sosyal bilgiler öğretiminde mizah. [Humor in social studies education]. (Unpublished Doctoral Thesis). Gazi University Institute of Educational Sciences.

Oruç, Ş. (2019). Öğrenci koçluğu el kitabı. [Student coaching handbook]. İstanbul: Buğrahan Publishing.

Ott, M., \& Pozzi. F. (2012). Digital games as creativity enablers for children. Behaviour \& Information Technology. 31(10), 1011-1019.

Özdamar, K. (2002). Paket programlar ile istatiksel veri analizi: SPSS-MINITAB (Çok değişkenli analizler). [Statistical data analysis with package programs: SPSS-MINITAB ((Multivariate analysis).] Eskişehir: Kaan Kitabevi.

Öztürk, C. (2012). Sosyal bilgiler ögretimi demokratik vatandaşlık eğitimi. [Social studies education democratic citizenship education]. 3.bs. Ankara: Pegem Academy.

Razon, N. (1985). Okul öncesi eğitimde oyunun, oyunda yetişkinin işlevi. [The function of game in preschool education and adult in game]. Preschool Education and Dissemination Seminar Journal. 2(3), 57-64

Ross, A., \& Willson V.L. (2004). Basic and advanced statistical tests: Writing results sections and creating tables and figures. AW Rotterdam, Netherlands: Sense Pub.

Sabanc1, O. (2015). Sosyal bilgiler ögretimi. [Social studies education]. Cengiz Dönmez, Kubilay Yazıcı (Eds.), Sosyal bilgiler ögretimi. [Social studies education (195-227). Ankara: Pegem Academy

Sadıkoğlu, A. (2017). Zekâ ve akıl oyunları dersinin değerler eğitimindeki rolünün öğretmen görüşlerine göre değerlendirilmesi. [Evaluation of the role of intelligence and mind games in value education according to teacher's opinions]. (Unpublished Master's Thesis). İstanbul Sabahattin Zaim University Marmara University Joint Master Program Senemoğlu, N. (2015). Gelişim öğrenme ve ögretim kuramdan uygulamaya. [From development learning and teaching theory to practice]. (24. Bs). Yarg1 Yayınlar1

Shapiro, S. S., \& Wilk, M. B. (1965). An analysis of variance test for normality (Complete samples). Biometrika. 52 (3/4), 591-611.

Soylu, T. (2019). Sosyal bilgiler öğretmenleri ve ortaokul öğrencilerinin kavram öğretimine ilişskin görüşlerinin belirlenmesi. [Determination of the views of social studies teachers and secondary school students on concept teaching]. (Unpublished Master's Thesis). Bolu Abant İzzet Baysal University Institute of Educational Sciences.

Sungur, S., \& Güngören, S. (2009). The role of classroom environment perceptions in selfregulated learning and science achievement. Elementary Education Online. v. 3: 883900.

Şeb, G., \& Bulut Serin, N. (2017). KKTC'de satranç eğitimi alan ve almayan ilkokul ve ortaokul öğrencilerinin problem çözme becerilerine yönelik algıları. [Perceptıons of trnc prmary and secondary school students receiving chess training towards problem solving skills] International Journal of New Trends in Arts, Sports \& Science Education. 6(3)58-67. 
Tabachnick, B. G., \& Fidell, S. L. (2013). Using multivariate statistics (Sixth edition). United States: Pearson Education.

Tokcan, H. (2015). Sosyal bilgilerde kavram ögretimi. [Concept teaching in social studies]. Ankara: Pegem Academy.

TTKB, (2013). Ortaokul ve İmam Hatip ortaokulu zekâ oyunları dersi öğretim programı, [Secondary school and Imam Hatip secondary school intelligence education program]. MEB 2013, 118.

Tural, A. (2011). Sosyal bilgilerde yapılandırmacı yaklaşımla kavram öğretimine yönelik model geliştirme. [Model development for concept teaching with constructivist approach in social studies]. (Unpublished Doctoral Thesis). Gazi University Institute of Educational Sciences, Ankara

Tüm Üstün Zekalılar Derneği. (2013). TÜZDER, Zekâ ve akıl oyunları eğitmenliği eğitimi notları kitapçığg. [TÜZZDER, Intelligence and mind games instructor training notes booklet.]. http://www.tuzder.org/ [19.12.2019] https://tuzder.org/egitimler/zeka-veakil-oyunlari-egitmenligi-egitimi/

Türkiye Zeka Vakfi. [Turkey Intelligence Foundation]. (2019). [19.12.2019] Türkiye Zeka Vakfi, https://www.tzv.org.tr/\#/

Yazıc1, H., \& Samanc1, O. (2003). İlköğretim öğrencilerinin sosyal bilgiler ders konuları ile ilgili bazı kavramları anlama düzeyleri. [Elementary students' level of understanding some concepts related to social studies course subjects]. Milli Eğitim Dergisi. 158. Bahar. [Journal of National Education. 158. Spring.]

Yılmaz, D. (2019). Akıl ve zekâ oyunlarının ilköğretim yedinci sınıf öğrencilerinin akıl yürütme becerilerine ve matematiksel tutumlarına etkisi. [The effect of mind games on the reasoning skill and mathematical attitude of 7th grades]. (Unpublished Master's Thesis). Necmettin Erbakan University, Konya 